\title{
Determinants of Audit Sanctions Severity
}

\author{
Stefano Azzali ${ }^{1} \&$ Tatiana Mazza ${ }^{1}$ \\ ${ }^{1}$ University of Parma, Italy \\ Correspondence: Tatiana Mazza, University of Parma, Kennedy street 6, 43121, Italy.
}

Received: February 11, 2020

Accepted: March 10, 2020

Online Published: March 24, 2020

doi:10.5430/ijba.v11n2p28

URL: https://doi.org/10.5430/ijba.v11n2p28

\begin{abstract}
This study investigates the effects of material weaknesses from auditing standards and of material misstatement from accounting standards on the audit sanctions severity. Using a unique database in the period 1983 - 2015, we find mixed results. Among the auditing standards, Internal Control Weaknesses lead to more severe audit sanctions than Quality Control, Other Auditors, Reporting and Audit Opinion Material Weaknesses Audit Sanctions, and to less severe audit sanctions than Professional Skepticism and Substantial Procedures. Among accounting standards, Fair Value misstatements are associated with more severe audit sanctions than Long-term investment, bank debts, and liquidity errors, and with lower severity of audit sanctions than Account receivables. Taken together, these findings suggest two main determinants of audit sanctions severity that auditors and accountants need to be aware: the area of internal control deficiencies and the area of fair value measurement. From these results, we learn that accounting and auditing standards errors have different likelihood of audit sanctions, and that auditors that aim to avoid sanctions need to invest mainly in the internal control assurance and in the fair value items of the financial reporting.
\end{abstract}

Keywords: audit sanction, material misstatements, material weaknesses, accounting standards, auditing standards

\section{Introduction}

\subsection{Summary}

Audit sanctions (AS) are direct measures of audit failure because they are consequences of material misstatements in the financial statement, or material weaknesses in the internal control system, not detected by auditors. They are widely studied in the literature with regard to their consequences, for example, on audit reputation, audit fees, audit market share. However, few studies have analyzed the determinants of AS, and specifically the determinants of AS severity. This paper focuses on two kinds of determinants: 1) Material Misstatement in Accounting Standards (MMAS); 2) Material Weaknesses in Auditing Standards (MWAS). The main responsibility of auditors performing audit quality is to avoid MMAS and MWAS, using their competencies and independence. When Public Oversight Boards (POB) or Civil Litigation (CL) detect MMAS and MWAS, auditors are sanctioned with different types of AS, and pay negative consequences, as documented by prior literature.

Determinants of AS severity are important because not all the violations of accounting and auditing standards lead to AS. We therefore need to classify infringements by severity, in both accounting standards and auditing standards. Both MWAS and MMAS increase the likelihood of AS, and loss of reputation, fees, and market share.

Using a unique database including AS imposed by the Italian POB and CL in the period 1983 - 2015, we analyze severity of AS and develop hypotheses on MMAS and MWAS. Classifying MMAS and MWAS by severity, consistently with literature (Church and Shefchik, 2012), we hypothesise that: 1) Internal Control MWAS are associated with more severe AS; 2) Fair Value MMAS are associated with more severe AS.

Results are mixed: Internal Control MWAS lead to more severe AS than Quality Control, Other Auditors, Reporting and Audit Opinion MWAS, and to less severe AS than Professional Skepticism and Substantial Procedures. Our first hypothesis is partially confirmed. Similarly, Fair Value MMAS are associated with more severe AS than Long-term investment, bank debts, and liquidity MMAS, and with lower severity of AS than Account receivables. The second hypothesis is also partially confirmed.

We contribute to the accounting literature as follow. We improve the strand of research on AS, analyzing two main determinants. MMAS and MWAS are the most important determinants of AS but very few studies classify them by severity. Our mixed results for both the 1st and 2 nd hypothesis signal that the different types of accounting and 
auditing standards can be classified taking into account their severity and risks of misstatements and weaknesses. Specifically, we interpret our finding on auditing standards to suggest that greater attention be given to Internal Controls Deficiencies (ICD) i.e. deficiencies related to internal control over financial reporting, and inappropriate reliance on internal controls for substantive testing. Internal Controls Deficiencies are in fact more likely to lead to more severe AS than deficiencies associated with other auditing standards, on for example reporting and audit opinions. Significant exceptions are the deficiencies related to professional skepticism and substantial procedures, which show more severe AS than ICD. We interpret our finding on accounting standards to suggest that greater attention be given to Fair Value Misstatements (e.g. financial instruments, goodwill), given that they lead to more severe AS than Misstatements associated with other accounting standards (e.g. long term investment, liquidity, and debt banks). Significant exceptions are misstatements related to account receivables, which show more severe AS than ICD.

\subsection{Relevant Scholarship}

FR severity has been measured with several methods. Palmrose et al., (2004) measure FR severity distinguishing between FRs which involve and do not involve fraud. They show that market reaction to FR involving fraud is more severe because: 1) the revelation of fraud is likely to increase the risk uncertainty because it reduces the reliability of management disclosures; 2 ) the revelation of fraud leads to increased costs related to contemporaneous litigation and regulatory actions, additional future monitoring, and future regulatory scrutiny. Hennes et al., (2008) investigate the effect FR severity (separating Errors and Irregularities) on Chief Executive Officer (CEO) and Chief Financial Officer (CFO) turnover and find that the severity increases the likelihood of external auditor dismissal. Hennes et al., (2014) uses severity as a proxy of monitoring failure, which is the responsibility of the auditors. Auditors are responsible for providing an opinion on the reliability of financial statements, and assuring the absence of material misstatements. In the case of FR, auditors can be held responsible and risk of AS, in terms of pecuniary sanctions or temporary prohibitions from the profession. The probability of CEO or CFO change is positively associated with higher restatement severity (Wang and Chou, 2010). They measure the FR severity with the following elements: 1) whether or not the FR involves core earnings (sales revenue, cost of sales, and on-going operating expenses), 2) the number of accounts affected, 3) the magnitude of amounts, and 4) the number of years restated. Finally, they use a measure of FR severity, which includes all the four elements. Burks, (2010) finds that CEO turnover is less sensitive than before Sarbanes-Oxley Act, given the decline of the severity of FR it brought in. He measures FR severity using a principal components analysis including: absolute value of earnings impact, earnings decrease, earnings increase, no impact on earnings, class action lawsuits related to FR, timeliness of FR. The likelihood of Managers turnover is positively associated with severe FR that reduce the income and severe FR increase the risks of the audit committee turnover (Srinivasan, 2005). Restatements severity are measures of audit failure, and they involve top managers that are accountable for reporting failure, increasing the likelihood of their dismissal. Mande and Son, (2013) measure FR severity with the more negative effect on net income. Acito et al., (2009) measure FR severity with their materiality and, analyzing FR related to leasing operations, support the notion that materiality judgments reflect both quantitative and qualitative considerations.

\subsection{Hypotheses}

The literature can be divided into studies on ICD and studies on external audit deficiencies on testing and using internal controls.

Prior research on the United States analyses companies disclosing ICD under Section 404 or 302 of the Sarbanes-Oxley Act: Ge and McVay (2005) find that material weaknesses are mainly associated with receivalbles, inventory, revenues, derivative, income tax accounts, lack of segregation of duties, inefficiencies in the period-end reporting process and accounting policies, and inappropriate account reconciliation. Doyle et al. (2007) find that determinants of material weaknesses depend by the type of control problems (entity or account-specific problem), and by the specific reason for the material weakness. Ashbaugh-Skaife et al. (2007) suggest the difference between finding and reporting a material weakness. Finally, Bedard and Graham (2011) show that there may be systematic differences in severity across types, and find that revenue issues are more likely to be severe and tax issue are more likely to be classified as at least significant deficiencies.

Research on external audit investigates the internal control weaknesses in code-law countries like Japan or Italy. Nishizaki et al. (2014) show that the reporting of material weaknesses has been much lower in Japan than in United States. Machida and Pronexus $(2009,2010)$ campare Japan and United States regarding items of material weaknesses: entity level controls, financial closing, personnel capacity, and segregation of duties are the items with highest weight in Japan while in the United States high weight items include documentation tasks and disclosure. In Italy, Mazza 
and Azzali (2015) find that the improvement of planning, scoping, testing, monitoring, competences and independence reduces severity and persistence of internal control deficiencies. They also find that revenues are the most severe type of internal control deficiency, while human resources and period end accounts are the most persistent.

Other research in United States investigates the SEC and PCAOB inspection reports on external control. Church and Shefchik (2012) investigate specific characters of audit deficiencies, which have implications for audit quality. Audit deficiencies common to specific auditing procedures are grouped into two main segments: internal controls and others. Results show that the frequency of deficiencies reflects that testing internal controls over financial reporting has increased considerably in recent years. Results show that most of deficiencies (88.6 percent) are not severe because they do not result in a misstatement. Messier et al. (2010), analyzing SEC and PCAOB enforcement actions against engagement quality reviewers, find that most of the sanctions do not involve Big4, and involve sanctions as a result of violation of auditing and accounting standards, including the lack of understanding of internal control. Most of them are significant sanctions, with prohibition of practicing for three or more years. However, any sanction is likely to affect the audit partner and the audit firm reputation.

Very little research investigates audit enforcement when the audit firm or auditor violate the accounting or auditing standards. In this context, we aim to extend Church and Shefchik (2012) and Messier et al. (2010). We answer the call of Church and Shefchik (2012) for further research to expand knowledge on audit enforcement effects. We follow the classification of Church and Shefchik (2012), which separates violations related to internal control from other violations of auditing standards. Starting from this classification, we extend previous literature, and we test whether internal control violations are positively associated with higher sanction severity.

Most prior literature is about the severity of ICD. We expect that ICD lead to more severe AS, given the wide attention they attract from regulators. This attention is present in Japan and Italy, where legislation similar to the Sarbanes-Oxley Act is in place.

\section{H1: Internal control violations are associated with higher severity than other audit standards violations}

While there is a stream of literature on the effects of fair value use (e.g. Hodder et al., 2014) on earnings quality (De George et al., 2016), there is little research on its the effects on AS. Most researches find that IFRS and the greater use of fair values by these standards bring significant benefits in terms of improved transparency and cross-country investments, lower capital costs, better comparability of financial reports. However, these benefits tend to vary significantly across firms and countries (De George et al., 2016). Several studies find that fair value measures are not always value relevant, and that they can be unverifiable and unreliable given their higher level of discretion and complexity (Hodder et al., 2014). Rodrìguez-Pérez et al. (2011) assessing the impact of fair-value accounting on financial statement analysis in a sample of Spanish companies, find that a change from historical-cost to fair-value accounting does not alter significantly analyst perceptions.

Church and Shefchik (2012), through the nature and the severity of audit deficiencies with implications for audit quality, define audit deficiencies associated with, e.g., revenues, fair value measurements, and other accounting estimates audit deficiencies. Results show a reduction of deficiencies related to revenues and other accounting estimates, while no changes in deficiencies associated with the fair value measurements, over the analyzed period (2004 - 2009).

We follow the classification of Church and Shefchik (2012), dividing fair value from other accounting standards violations. In view of the risks of verifiability and reliability of fair value measurement (Hodder et al., 2014), we expect higher severity of AS when auditors violate accounting standards that involve fair value measurements and violations.

H2: Fair value violations are associated with higher severity than other accounting standards violations

\section{Method}

\subsection{Sampling Procedures}

We hand-collected the Italian POB reports and the CL that includes AS imposed on auditors. We made a content analysis of these documents to identify firms, auditors and financial statements involving the audit error. Our sample includes 39 companies for which financial statements were audited by an auditor who received AS from the Italian POB or as a consequence of CL. Our analysis is based on this sample of financial statements with related AS.

The hand collected POB reports cover the period 1992-2015, and the hand-collected data on AS from CL reports cover the period 1983 - 2011. We retrieved documents for this period, and read the content of the POB report and the 
CL to identify financial statements. For the 39 firms, we have finally 108 firm-years observations on which we run the analysis (Table 1).

Table 1. Sample

\begin{tabular}{ll}
\hline Description & N \\
\hline Italian companies listed and non-listed with external audit that received a sanction & 39 \\
\hline Final number of observations for the financial statements of the period 1983-2015 & 108 \\
\hline
\end{tabular}

\subsection{Research Design}

We investigate Hypotheses 1 with the following regression model:

$A S$ Severity $=\beta 1$ internal control $+\beta 2$ other auditing standards $+\beta n$ control variables $+e$

We investigate Hypothesis 2 with the following regression model:

$A S$ Severity $=\beta 1$ fair value $+\beta 2$ other accounting standards $+\beta n$ control variables $+e$

Our dependent variable for $\mathrm{H} 1$ and for $\mathrm{H} 2$ is AS severity. We measure AS severity separately for sanctions imposed by POB and CL. We measure POB AS severity classifying sanctions as Pecuniary Sanctions (PS) and Temporary Prohibition (TP). PS includes the imposition of administrative pecuniary sanctions on natural and legal persons and TP includes a temporary prohibition, of up to three years' duration, banning the statutory auditor, the audit firm or the key audit partner from carrying out statutory audits and/or signing audit reports (Table 2). The CL are fines imposed by courts. We did a content analysis to identify the type and amount or duration of the sanction, and created four categories based on quartile. If the PS has an amount lower than the first quartile (€ 695,000in CL AS and €90,000 in POB AS), the severity variable takes value 1 . Similarly, if the TP has a number of months lower than the first quartile (18 months), the severity variable takes value 1 . The second and third quartiles are then used to create an ordinal variable for severity from 1 to 4 (see Table 2 for the values of quartiles used). We added a category with value 0 when the auditor has been sued but has not received a sanction. Finally, we create the variable "AS severity" using the five categories of the CV AS and the four categories of POB AS. This procedure makes it possible to investigate the relation of internal control and fair value with severity independently of the type of responsibility (Public or Private).

Table 2. Severity

\begin{tabular}{|c|c|c|c|}
\hline Civil litigation & CONSOB & Severity & $\%$ \\
\hline Sued but no sanction & - & $(0)$ & 42 \\
\hline $\begin{array}{l}\text { Pecuniary sanction }<25^{\text {th }} \\
\text { percentile } \\
\text { (pecuniary sanctions } \\
<=695.000 € \text { ) }\end{array}$ & $\begin{array}{l}\text { Pecuniary sanction or Temporary Prohibition } \\
<25^{\text {th }} \text { percentile } \\
\text { (pecuniary sanctions }<=90,000 € \text { ) } \\
\text { (temporary prohibition }<=18 \text { months) }\end{array}$ & $\begin{array}{l}\text { (1) Low } \\
\text { Severity }\end{array}$ & 21 \\
\hline $\begin{array}{l}\text { Pecuniary sanction } \\
\text { between } 25^{\text {th }} \text { and } 50^{\text {th }} \\
\text { percentile } \\
(695.000 €<\text { pecuniary } \\
\text { sanctions }<=1,786,941 € \text { ) }\end{array}$ & $\begin{array}{l}\text { Pecuniary sanction or Temporary Prohibition } \\
\text { between } 25^{\text {th }} \text { and } 50^{\text {th }} \text { percentile } \\
(90,000 €<\text { pecuniary sanctions }<=150,000 €) \\
\text { (18 months }<\text { temporary prohibition }<=24 \text { months) }\end{array}$ & (2) & 19 \\
\hline $\begin{array}{l}\text { Pecuniary sanction } \\
\text { between } 50^{\text {th }} \text { and } 75^{\text {th }} \\
\text { percentile } \\
(1,786,941 €<\text { pecuniary } \\
\text { sanctions }<=4,544,821 €)\end{array}$ & $\begin{array}{l}\text { Pecuniary sanction or Temporary Prohibition } \\
\text { between } 50^{\text {th }} \text { and } 75^{\text {th }} \text { percentile } \\
(150,000 €<\text { pecuniary sanctions }<=350,000 €) \\
\text { ( } 24 \text { months }<\text { temporary prohibition }<=24 \text { months) }\end{array}$ & (3) & 17 \\
\hline Pecuniary sanction $>75^{\text {th }}$ & Pecuniary sanction or Temporary Prohibition & (4) High & 1 \\
\hline
\end{tabular}




\begin{tabular}{lll}
\hline percentile & $>75^{\text {th }}$ percentile & Severity \\
$($ pecuniary sanctions $>$ & $($ pecuniary sanctions $>350,000 €)$ & \\
$4,544,821 €)$ & (temporary prohibition $>24$ months) & \\
\hline = Final number of observations & $100 \%$ \\
\hline
\end{tabular}

Independent variables for $\mathrm{H} 1$ are the variables of interest (MW related to internal control and the MW related to other auditing principles, e.g. quality control, documentation, plan and risk assessment, professional scepticism, other auditor, substantial procedures, sampling, related parties and group, reporting, and audit opinion) and control variables. For the measurement of AS severity we classify the MW in relationship to auditing principles. For each firm-year-sanction observation, we create 11 dummy variables for auditing standards giving value 1 if the POB report or the CL report contains a reference to the specific standard, and otherwise 0. See Appendix A for the list of standards. We give value 1 where the documents refer directly to the number of the standards and indirectly to the account/element investigated. One AS usually has more than one category of issue. Following Church and Shefchik (2012), we use a classification that separates internal control from other MW related to auditing standards. This reflects the emphasis on the critical nature of these internal controls in US and Italian legislation since the financial scandals involving listed companies (Sarbanes-Oxly Act 2002 in the United States, Law 262/2005 in Italy).

Independent variables for $\mathrm{H} 2$ are the variables of interest (MM from Fair value and other MM from other accounting principles, e.g. long term investment, inventory, subsidiary, liquidity, account payables, bond debts, bank debts, tax, and off-balance sheet). Deficiencies that involve an error in the financial statement are financial statement restatement, failure to identify and appropriately address a departure from an accounting standard, failure to identify and appropriately address an accounting error. Conversely, deficiencies that do not involve a misstatement in the financial statement are failure to test an account and/or an assertion, failure to adequately or properly evaluate an accounting issue and/or whether the accounting treatment was appropriate, failure to perform or document sufficient procedures/analyses when testing. Because fair value measures are increasingly in the European Union after the mandatory adoption of International Financial Reporting Standard for listed companies, we use the Church and Shefchik (2012) classification of audit deficiencies separating fair value from other. We group financial instruments, intangibles, goodwill and derivatives into one dummy variable if there is at least one of these accounting standards violated in order to have one variable for the regression model to test $\mathrm{H} 2$.

Control variables are IFRS, listed, BigN, litigation risk, complexity, leverage, company importance, delay. We include as a control variable a dummy for the use of IFRS or Italian accounting standards, given the long time period of the sample when companies were free to use one or the other standard. As control variables we used listed, CONSOB, BigN, litigation risk, complexity, leverage, company importance, and delay. We hand collected type of accounting standard, net income, equity and total assets from the financial statements, and auditor name, delay and industry from the CONSOB report and civil litigation in order to calculate these variables.

\section{Results}

\subsection{Statistics and Data Analysis}

Table 3 shows the descriptive statistics of AS, classified by severity ( $0=$ low severity and $1=$ high severity) and in the following four classes: audit sanctions from auditing standards (Panel A), AS from accounting standards (Panel B), control variables (Panel C).

Panel A includes AS from auditing standards related to internal control or other auditing standards (quality control, documentation, plan and risk assessment, professional skepticism, other auditor substantial procedures, sampling, related parties and group, reporting, and audit opinions). The more severe AS occur in documentation (38.5\%), plan and risk assessment $(61.5 \%)$, substantial procedures (100\%), related parties and group (41.0\%), audit opinion $(59.0 \%)$, and sampling (41.0\%). Substantial procedures (87\%), and audit opinion (84.1\%) also reveal high percentages of AS in the sample including the less severe AS.

Panel B includes AS from accounting standards related to fair value or other accounting standard violations. We find that the most severe AS in fair value accounts are in intangibles (28.2\%) and goodwill (23.1\%). Among the other accounts, the most severe AS are imposed for long-term investment (41\%), and accounts receivables (48.7\%).

Finally, Panel C shows that our sample of more severe AS mainly comprises listed companies (84.6\%), those audited by Big4 (69.2\%), in the finance industry (46.2\%), and with a significant delay in the issuance of the AS (5.641 year from the date of the financial reporting). The sample with less severe AS, on the other hand, includes a lower 
percentage of listed companies (68.1\%), a lower percentage of companies audited by Big4 (59.4\%), a higher percentage of companies operating in the finance industry (65.2\%), and higher delay (12.145). Finally, IFRS companies show a higher percentage of more severe AS (43.6\%) than companies with less severe AS (10.1\%).

Table 3. Descriptive statistics

\begin{tabular}{|c|c|c|c|c|c|c|c|c|c|c|c|}
\hline \multirow[b]{2}{*}{$\begin{array}{l}\text { Panel A: Auditing } \\
\text { standards }\end{array}$} & \multicolumn{5}{|c|}{ Severity_dummy $=1$} & \multicolumn{6}{|c|}{ Severity_dummy $=0$} \\
\hline & Mean & SD & p25 & p50 & p75 & Mean & SD & p25 & p50 & p75 & $\begin{array}{l}\text { Mean } \\
\text { diff. }\end{array}$ \\
\hline $\begin{array}{l}\text { Material Weakness related to } \\
\text { INTERNAL CONTROL }\end{array}$ & 0.256 & 0.442 & 0.000 & 0.000 & 1.000 & 0.391 & 0.492 & 0.000 & 0.000 & 1.000 & -0.135 \\
\hline \multicolumn{12}{|l|}{$\begin{array}{l}\text { Material Weakness related to } \\
\text { OTHER auditing standards: }\end{array}$} \\
\hline quality control & 0.205 & 0.409 & 0.000 & 0.000 & 0.000 & 0.145 & 0.355 & 0.000 & 0.000 & 0.000 & 0.060 \\
\hline documentation & 0.385 & 0.493 & 0.000 & 0.000 & 1.000 & 0.391 & 0.492 & 0.000 & 0.000 & 1.000 & -0.007 \\
\hline plan and risk assessment & 0.615 & 0.493 & 0.000 & 1.000 & 1.000 & 0.246 & 0.434 & 0.000 & 0.000 & 0.000 & 0.369 \\
\hline profession skepticism & 0.282 & 0.456 & 0.000 & 0.000 & 1.000 & 0.159 & 0.369 & 0.000 & 0.000 & 0.000 & 0.123 \\
\hline other auditor & 0.077 & 0.270 & 0.000 & 0.000 & 0.000 & 0.333 & 0.475 & 0.000 & 0.000 & 1.000 & -0.256 \\
\hline substantial procedures & 1.000 & 0.000 & 1.000 & 1.000 & 1.000 & 0.870 & 0.339 & 1.000 & 1.000 & 1.000 & 0.130 \\
\hline sampling & 0.410 & 0.498 & 0.000 & 0.000 & 1.000 & 0.203 & 0.405 & 0.000 & 0.000 & 0.000 & 0.207 \\
\hline related parties and group & 0.410 & 0.498 & 0.000 & 0.000 & 1.000 & 0.362 & 0.484 & 0.000 & 0.000 & 1.000 & 0.048 \\
\hline reporting & 0.256 & 0.442 & 0.000 & 0.000 & 1.000 & 0.232 & 0.425 & 0.000 & 0.000 & 0.000 & 0.025 \\
\hline audit opinion & 0.590 & 0.498 & 0.000 & 1.000 & 1.000 & 0.841 & 0.369 & 1.000 & 1.000 & 1.000 & -0.251 \\
\hline
\end{tabular}

Panel B: Accounting standards

Mean S p25

Mean SD

Mean

Material Misstatement related to FAIR VALUE

\begin{tabular}{llllllllllll}
\hline short term fin.instruments & 0.077 & 0.270 & 0.000 & 0.000 & 0.000 & 0.203 & 0.405 & 0.000 & 0.000 & 0.000 & -0.126 \\
\hline intangibles & 0.282 & 0.456 & 0.000 & 0.000 & 1.000 & 0.174 & 0.382 & 0.000 & 0.000 & 0.000 & 0.108 \\
\hline goodwill & 0.231 & 0.427 & 0.000 & 0.000 & 0.000 & 0.203 & 0.405 & 0.000 & 0.000 & 0.000 & 0.028 \\
\hline derivatives & 0.051 & 0.223 & 0.000 & 0.000 & 0.000 & 0.188 & 0.394 & 0.000 & 0.000 & 0.000 & -0.137 \\
\hline $\begin{array}{l}\text { Material Misstatement related } \\
\text { to OTHER accounting stand.: }\end{array}$ & & & & & & & & & & \\
\hline PPE & 0.026 & 0.160 & 0.000 & 0.000 & 0.000 & 0.232 & 0.425 & 0.000 & 0.000 & 0.000 & -0.206 \\
\hline long term investment & 0.410 & 0.498 & 0.000 & 0.000 & 1.000 & 0.565 & 0.499 & 0.000 & 1.000 & 1.000 & -0.155 \\
\hline inventory & 0.179 & 0.389 & 0.000 & 0.000 & 0.000 & 0.058 & 0.235 & 0.000 & 0.000 & 0.000 & 0.122 \\
\hline account receivables & 0.487 & 0.506 & 0.000 & 0.000 & 1.000 & 0.420 & 0.497 & 0.000 & 0.000 & 1.000 & 0.067 \\
\hline subsidiary & 0.026 & 0.160 & 0.000 & 0.000 & 0.000 & 0.159 & 0.369 & 0.000 & 0.000 & 0.000 & -0.134 \\
\hline liquidity & 0.051 & 0.223 & 0.000 & 0.000 & 0.000 & 0.377 & 0.488 & 0.000 & 0.000 & 1.000 & -0.326 \\
\hline account payables & 0.282 & 0.456 & 0.000 & 0.000 & 1.000 & 0.072 & 0.261 & 0.000 & 0.000 & 0.000 & 0.210 \\
\hline bond debts & 0.051 & 0.223 & 0.000 & 0.000 & 0.000 & 0.217 & 0.415 & 0.000 & 0.000 & 0.000 & -0.166 \\
\hline
\end{tabular}




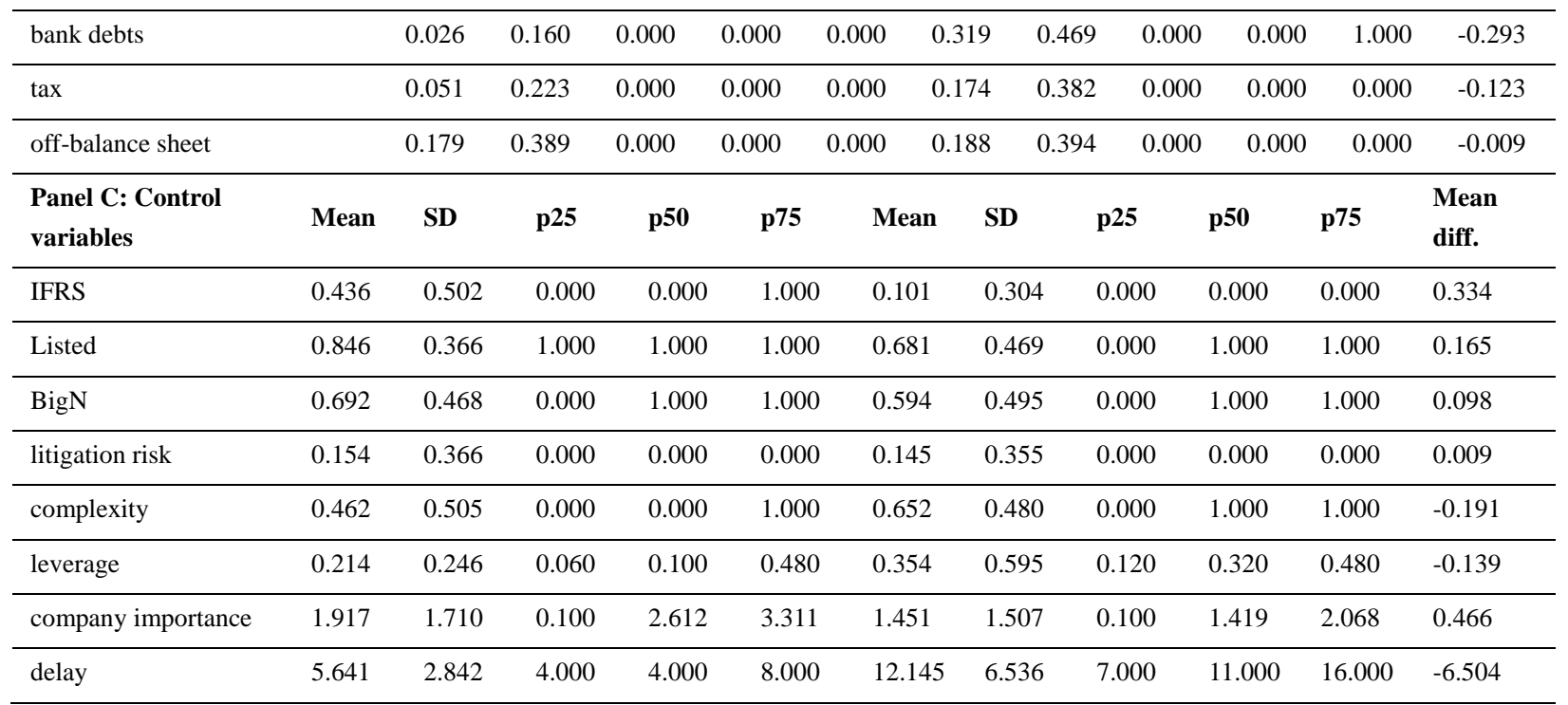

Refer to Appendix A for variable definitions.

Table 4 shows the results for $\mathrm{H} 1$ and $\mathrm{H} 2$. The OLS regression shows the coefficients of all auditing and accounting standards, all the regimes and the control variables, showing on their relationship with AS severity. Differences in coefficients show the different relation with AS severity for each auditing standard vs internal control weaknesses and for each accounting standard vs the fair value standard Material Misstatement.

Results for $\mathrm{H} 1$ show that material weaknesses related to internal control are associated with higher severity than material weaknesses related to quality control, other auditor, reporting or audit opinion standards violation. However, deficiencies from internal control are associated with lower severity than deficiencies from professional scepticism and substantial procedures standards violation. Our expectation of higher severity reflecting regulators' greater attention to internal control, is partially confirmed.

Results for $\mathrm{H} 2$ show that material misstatements from fair value are associated with higher severity than material misstatements from long-term investment, liquidity or bank debt standards violation. However, fair value misstatements are associated with lower severity than receivables account standards violation. The risks of verifiability and reliability of fair value measurement (Hodder et al., 2014) are associated with higher severity. However, the evaluation of the receivables account is even more severe, given the difficulties in measuring losses, during the long period of financial crisis.

The coefficients of control variables show that AS severity is significantly and positively associated with the finance industry. AS from accounting and auditing standards are more severe when the company is a bank, an insurance firm or other type of financial firm.

Table 4. Multivariate analysis of accounting and auditing standards

\begin{tabular}{llllll}
\hline Severity & OLS regression & Differences in coefficients & Difference & p-value \\
\hline & Estimate & p-value & & & \\
\hline internal control & 0.264 & 0.538 & & 0.461 & 0.000 \\
\hline quality control & -0.198 & 0.685 & internal control - quality control & 0.857 & 0.356 \\
\hline documentation & -0.594 & 0.129 & internal control - documentation & -0.049 & 0.468 \\
\hline plan and risk assessment & 0.313 & 0.370 & internal control - plan and risk assessment & -0.149 & 0.013 \\
\hline professional skepticism & 0.413 & 0.575 & internal control - professional skepticism & 0.295 & 0.021 \\
\hline other auditor & -0.032 & 0.935 & internal control - other auditor & -2.082 & 0.000 \\
\hline substantial procedures & 2.346 & 0.000 & internal control - substantial procedures & & \\
\hline
\end{tabular}




\begin{tabular}{|c|c|c|c|c|c|}
\hline sampling & 0.384 & 0.439 & internal control - sampling & -0.120 & 0.225 \\
\hline related parties and group & 0.252 & 0.542 & internal control - related parties and group & 0.012 & 0.519 \\
\hline reporting & -0.006 & 0.986 & internal control - reporting & 0.269 & 0.078 \\
\hline audit opinion & -0.888 & 0.085 & internal control - audit opinion & 1.152 & 0.000 \\
\hline fair value & -0.444 & 0.215 & & & \\
\hline PPE & -0.450 & 0.208 & fair value - PPE & 0.005 & 0.468 \\
\hline long term investment & -0.967 & 0.000 & fair value - long term investment & 0.523 & 0.000 \\
\hline inventory & -1.245 & 0.002 & fair value - inventory & 0.800 & 0.672 \\
\hline account receivables & 0.016 & 0.965 & fair value - account receivables & -0.460 & 0.000 \\
\hline subsidiary & -0.269 & 0.721 & fair value - subsidiary & -0.176 & 0.836 \\
\hline liquidity & -1.057 & 0.001 & fair value - liquidity & 0.612 & 0.013 \\
\hline account payables & 0.036 & 0.931 & fair value - account payables & -0.480 & 0.566 \\
\hline bond debts & 1.608 & 0.106 & fair value - bond debts & -2.053 & 0.468 \\
\hline bank debts & -1.103 & 0.004 & fair value - bank debts & 0.659 & 0.096 \\
\hline $\operatorname{tax}$ & 1.187 & 0.224 & fair value - tax & -1.631 & 0.848 \\
\hline off-balance sheet & 0.905 & 0.099 & fair value - off-balance sheet & -1.349 & 0.210 \\
\hline IFRS & -0.359 & 0.331 & & & \\
\hline Listed & 0.400 & 0.346 & & & \\
\hline CONSOB & - & & & & \\
\hline BigN & 0.450 & 0.128 & & & \\
\hline litigation risk & 0.181 & 0.522 & & & \\
\hline complexity & -1.607 & 0.000 & & & \\
\hline leverage & -0.020 & 0.645 & & & \\
\hline company importance & 0.124 & 0.123 & & & \\
\hline delay & 0.019 & 0.289 & & & \\
\hline intercept & 0.845 & 0.268 & & & \\
\hline Observations & 108 & & & & \\
\hline
\end{tabular}

Coefficient $p$-values are two-tailed and robust standard errors White t-test p-values are one-tailed. Refer to Appendix A for variable definitions. Either an OLS regression or a probit regression can be used with no difference because the focus is on t-test differences in coefficients and their p-value, not the magnitude of coefficients.

\subsection{Ancillary Analyses}

To test the robustness of our main results, we perform an additional test, using a different measure of AS severity. Specifically, we classify AS into two categories. The first (low severity) includes pecuniary sanctions and temporary prohibitions from POB and CL under the first percentile, that is 1,786,941 euros for CL pecuniary sanctions and 125,000 for POB pecuniary sanctions, and 18 months for POB temporary prohibitions. The second category (high severity) includes all the other AS. Using the new measures, $64 \%$ of AS are classified as low severity, and $36 \%$ as high severity. Results confirm the findings of the main analysis (untabulated).

\section{Discussion}

This study analyses the determinants of AS severity. While prior literature investigates extensively the consequences of AS and audit inspections on auditor reputation, audit fees, and audit market share, very few studies exist on the determinants of AS, or on the role played by different types of accounting and auditing standards. We focus on two 
main kinds of determinants: 1) Material Misstatement in Accounting Standards (MMAS); 2) Material Weaknesses in Auditing Standards (MWAS).

One of the main responsibilities of the auditors is to detect material misstatements in the financial statement and material weaknesses in the internal control system of the audited company. When POB or CL detect MMAS and MWAS, auditors are sanctioned with different types of AS, and pay economic costs (loss of audit fees, market share) and non-economic costs (audit reputation and brand name).

Expecting that not all the violations of accounting and auditing standards lead to AS, and classifying them by severity, we hypothesize that the two types of standards are associated with AS in different ways.

Our database includes Italian AS in the period 1983 - 2015 and is a unique set of information hand-collected from POB and CL reports. Classifying MMAS and MWAS by severity, consistently with the literature (Church and Shefchik, 2012), we hypothesize that: 1) Internal Control MWAS are associated with more severe AS; 2) Fair Value MMAS are associated with more severe AS.

We find mixed results: Internal Control MWAS lead to more severe AS than Quality Control, Other Auditors, Reporting and Audit Opinion MWAS and to less severe AS than Professional Skepticism and Substantial Procedures. Similarly, Fair Value MMAS are associated with more severe AS than Long-term investment, bank debts, and liquidity MMAS and with lower severity of AS than Account receivables. Hypothesis 1 and Hypothesis 2 are partially confirmed.

Our findings on auditing standards reveal the need to pay attention to ICD such as deficiencies related to internal control over financial reporting, and inappropriate reliance on internal controls for substantive testing. It is in fact more likely that severe AS are associated with material weaknesses in the internal control system than AS from deficiencies related to most types of auditing standards. Our finding on accounting standards indicates the need to give more attention to Fair Value Misstatements (occurring in areas such as financial instruments and goodwill). In fact, it is more likely that severe AS are associated with Misstatements related to financial instruments, than misstatements relating to types of other accounting standards such as long term investment, liquidity, and debt banks.

Limitations of this study include sample size and composition. The sample includes a low number of observations, given the limited size of financial market in Italy and given that the POB has controlled auditor quality only in recent years. It is likely that in the future, more data will be available on AS, and results will be improved. Lastly, our sample includes both POB and CL sanctions, and both pecuniary sanctions and temporary prohibitions, and again because of the limited number of observations, we are not able to test the specific effect of each of these a AS.

\section{Conclusion}

We investigate the effects of material weaknesses from auditing and accounting standards on the audit sanctions severity. The analysis of a unique database of audit sanctions reveals mixed results with criticisms mostly related to the Internal Control Weaknesses and Fair Value misstatements. From these results, we learn that accounting and auditing standards errors have different likelihood of audit sanctions, and that auditors that aim to avoid sanctions need to invest mainly in the internal control assurance and in the fair value items of the financial reporting.

Limitations of this study are related, e.g., to the sample size. We hand-collected audit sanctions in the period 1992-2015 from POB reports and in the period 1983 - 2011 from CL reports and we obtain 108 observations for our analysis. However, this represent a unique and private database.

\section{Acknowledgements}

This research has financially been supported by the Programme "FIL-Quota Incentivante" of University of Parma and co-sponsored by Fondazione Cariparma. The proof reading has been followed by Professor Lois Clegg.

\section{References}

Acito, A. A., Burks, J. J., \& Johnson, W. B. (2009). Materiality decisions and the correction of accounting errors. Accounting Review, 84(3), 659-688. https://doi.org/10.2308/accr.2009.84.3.659

Ashbaugh-Skaife, H., Collins, D., \& Kinney, W. (2007). Thediscovery and reporting of internal control deficienciesprior to Sarbanes-Oxley Act-mandated audits. Journal of Accounting and Economics, 44(1-2), 166-92. https://doi.org/10.1016/j.jacceco.2006.10.001

Bedard, J. C., \& Graham, L. (2011). Detection and severityclassifications of Sarbanes-Oxley Section 404 internalcontrol deficiencies. The Accounting Review, 86(3), 825-55. https://doi.org/10.2308/accr.00000036

Burks, J. (2010). Disciplinary measures in response to restatements after Sarbanes-Oxley. Journal of Accounting and 
Public Policy, 29, 195-225. https://doi.org/10.1016/j.jaccpubpol.2010.03.002

Church, B. K., \& Shefchik, L. B. (2012). PCAOB Inspections and Large Accounting Firms. Accounting Horizons, 26(1), 43-63. https://doi.org/10.2308/acch-50077

Doyle, J., Ge, W., \& McVay, S. (2007). Determinants of weaknesses in internal control over financial reporting. Journal of Accounting and Economics, 44(1-2), 193-223. https://doi.org/10.1016/j.jacceco.2006.10.003

Ge, W., \& McVay, S. (2005). The disclosure of material weaknesses in internal control after the Sarbanes-Oxley Act. Accounting Horizons, 19(3), 137-58. https://doi.org/10.2308/acch.2005.19.3.137

De George, E. T., Li, X., \& Shivakumar, L. (2016). A review of the IFRS adoption literature. Review of Accounting Studies, 21(3), 898-1004. https://doi.org/10.1007/s11142-016-9363-1

Hennes, K. M., Leone, A. J., \& Miller, B. P. (2008). The importance of distinguishing errors from irregularities in restatement research: The case of restatements and CEO/CFO turnover. Accounting Review, 83(6), 1487-1519. https://doi.org/10.2308/accr.2008.83.6.1487

Hennes, K. M., Leone, A. J., \& Miller, B. P. (2014). Determinants and market consequences of auditor dismissals after accounting restatements. Accounting Review, 89(3), 1051-1082. https://doi.org/10.2308/accr-50680

Hodder, L., Hopkins, P., \& Schipper, K. (2014). Fair value measurement in financial reporting. Foundations and Trends® in Accounting, 8(3-4), 143-270. https://doi.org/10.1561/1400000030

Machida, Y., \& Pronexus. (2009). Analysis on internal control reports. (Naibu Tousei Houkoku no Jittai Chosa Kekka no Bunseki in Japanese). Weekly Report on Financial Accounting (Shukan Keiei Zaimu), 2927, 22-29.

Machida, Y., \& Pronexus. (2010). About internal control reports submitted by firms in March 2010. (2010-nen 3-gatsu Kessan Kigyo no Naibu Tousei Houkoku no Jittai Chosa Kekka ni Tsuite in Japanese). Weekly Report on Financial Accounting (Shukan Keiei Zaimu), 2974, 14-19.

Mande, V., \& Son, M. (2013). Do financial restatements lead to auditor changes?. Auditing: A Journal of Practice \& Theory, 32(2), 119-145. https://doi.org/10.2308/ajpt-50362

Mazza, T., \& Azzali, S. (2015). Effects of internal audit quality on the severity and persistence of controls deficiencies. International Journal of Auditing, 19(3), 148-165. https://doi.org/10.1111/ijau.12044

Messier, W. F., Kozloski, T. M., \& Kochetova-kozloski, N. (2010). An Analysis of SEC and PCAOB Enforcement Actions against Engagement Quality Reviewers. Auditing: A Journal of Practice \& Theory, 29(2), 233-252. https://doi.org/10.2308/aud.2010.29.2.233

Nishizaki, R., Takano, Y., \& Takeda, F. (2014). Information content of internal control weaknesses: The evidence from Japan. The International Journal of Accounting, 49(1), 1-26. https://doi.org/10.1016/j.intacc.2014.01.009

Rodrìguez-Pérez, G., Slof, J., Solà, M., Torrent, M., \& Vilardell, I. (2011). Assessing the impact of fair-value accounting on financial statement analysis: a data envelopment analysis approach. Abacus, 47(1), 61-84. https://doi.org/10.1111/j.1467-6281.2011.00331.x

Srinivasan, S. (2005). Consequences of Financial Reporting Failure for Outside Directors: Evidence from Accounting Restatements and Audit Committee Members. Journal of Accounting Research, 43, 291-334. https://doi.org/10.1111/j.1475-679x.2005.00172.x

Wang, Y.-F., \& Chou, L.-T. L. (2010). Impact of Restatement Characteristics and Subsequent Earnings management on Post-Sox Executive Turnover. Review of Business, 31(2), 24-51.

\section{Appendix}

Appendix A - Variable Definitions

\begin{tabular}{|c|c|}
\hline \multicolumn{2}{|l|}{ Dependent Variables } \\
\hline Severity & $\begin{array}{l}=0 \text { if sued but not sanction; from } 1 \text { to } 4 \text { based on the quartile of severity } \\
\text { of temporary and pecuniary sanctions; } 5 \text { if banning }\end{array}$ \\
\hline \multicolumn{2}{|l|}{ Independent Variables } \\
\hline \multicolumn{2}{|l|}{ MWAS } \\
\hline internal control & $=1$ if auditors violated ISA $610 ; 0$ otherwise \\
\hline
\end{tabular}




\section{Control}

\begin{tabular}{|c|c|c|}
\hline \multirow{10}{*}{ Others } & quality control & $=1$ if auditors violated ISA $220 ; 0$ otherwise \\
\hline & documentation & $=1$ if auditors violated ISA $230 ; 0$ otherwise \\
\hline & plan and risk assessment & $=1$ if auditors violated ISA 300,315 and $320 ; 0$ otherwise \\
\hline & profession skepticism & $=1$ if auditors violated ISA $200 ; 0$ otherwise \\
\hline & other auditors & $=1$ if auditors violated ISA $600 ; 0$ otherwise \\
\hline & substantial procedures & $=1$ if auditors violated ISA 540; 0 otherwise \\
\hline & sampling & $=1$ if auditors violated ISA 530; 0 otherwise \\
\hline & related parties and group & $=1$ if auditors violated ISA 550 and $600 ; 0$ otherwise \\
\hline & reporting & $=1$ if auditors violated ISA 260 and $265 ; 0$ otherwise \\
\hline & audit opinion & $=1$ if auditors violated ISA 700; 0 otherwise \\
\hline \multicolumn{3}{|l|}{ MMAS } \\
\hline \multirow{4}{*}{ Fair Value } & $\begin{array}{l}\text { short term financial } \\
\text { instruments }\end{array}$ & $=1$ if auditors violated IAS 39 or OIC $32 ; 0$ otherwise \\
\hline & intangibles & $=1$ if auditors violated IAS 38 or OIC $24 ; 0$ otherwise \\
\hline & goodwill & $=1$ if auditors violated IAS 38 or OIC $24 ; 0$ otherwise \\
\hline & derivatives & $=1$ if auditors violated IAS 39 or OIC $32 ; 0$ otherwise \\
\hline \multirow{11}{*}{ Others } & PPE & $\begin{array}{l}=1 \text { if auditors violated IAS } 16 \text { or OIC } 16 \text { (without revaluation model); } \\
0 \text { otherwise }\end{array}$ \\
\hline & long term investment & $=1$ if auditors violated IAS 39 or OIC $32 ; 0$ otherwise \\
\hline & inventory & $=1$ if auditors violated IAS 2 or OIC $13 ; 0$ otherwise \\
\hline & account receivables & $=1$ if auditors violated IAS 39 or OIC $15 ; 0$ otherwise \\
\hline & subsidiary & $=1$ if auditors violated IAS 39 or OIC $15 ; 0$ otherwise \\
\hline & liquidity & $=1$ if auditors violated IAS 39 or OIC 14; 0 otherwise \\
\hline & account payables & $=1$ if auditors violated IAS 39 or OIC $19 ; 0$ otherwise \\
\hline & bond debts & $=1$ if auditors violated IAS 39 or OIC $19 ; 0$ otherwise \\
\hline & bank debts & $=1$ if auditors violated IAS 39 or OIC $19 ; 0$ otherwise \\
\hline & $\operatorname{tax}$ & $=1$ if auditors violated IAS 12 or OIC $25 ; 0$ otherwise \\
\hline & off-balance sheet & $=1$ if auditors violated IAS 17,37 or OIC 12,$22 ; 0$ otherwise \\
\hline
\end{tabular}

\section{Control variables}

\begin{tabular}{ll} 
IFRS & $=1$ if listed and finance companies after 2005; 0 otherwise \\
\hline listed & $=1$ if listed in Milan stock exchange; 0 otherwise \\
\hline BigN & $=1$ if the audit firm is PWC, Deloitte, KPMG, Ernst \& Young; 0 otherwise \\
\hline litigation risk & $=1$ if the audited firms is in the following industries: construction, \\
& wholesale and retail trade; repair of motor vehicles and motorcycles, \\
& information and communication; 0 otherwise \\
\hline complexity & $=1$ if the audited firms is in the financial industry; 0 otherwise \\
\hline ROE & $=$ net income / shareholder's equity \\
\hline leverage & $=$ equity / total asset \\
\hline company importance & $=$ total assets of client / market share based on total assets of audit firm \\
\hline delay & $=$ sanction year - financial statement year
\end{tabular}

